\title{
ANALISIS BIAYA KUALITAS MENGGUNAKAAN METODE ACTIVITY BASED COSTING (ABC) PADA USAHA MIKRO KECIL MENENGAH (UMKM)
}

\author{
Irwan Sukendar, Andre Sugiyono, Fauyan Supardi \\ Program Studi Teknik Industri \\ Fakultas Teknologi Industri \\ Universitas Islam Sultan Agung \\ Jl. Raya Kaligawe km 4 Semarang, (024) 6583584/(024) 6583455 \\ e-mail: irwan@unissula.ac.id, fauyan_supardi@student.unissula.ac.id
}

\begin{abstract}
UMKM Bandeng Presto Pak Han is a home business that is engaged in making presto milkfish. Based on the results of interviews with business owners, every day in every production there is definitely damaged pressure-cooked milkfish that will not be sold to the market and will be declared a reject product. The average reject product reaches a percentage of $4 \%-7 \%$ in each production. The reject products and the remaining sales for the day will be taken by the collectors and will be resold at half price which will result in decreased profit received by Bandeng Presto Pak Han. The research aims to calculate the cost of quality that has never been calculated before, and to identify what costs are incurred in an effort to improve product quality and increase sales profits.. From observations and calculations of standard time and calculation of all aspects of production costs, it is concludedActivity Based Costing (ABCBased on the results of data processing that has been done with Activity Based Costing $(A B C)$. From the results of the calculation of the cost of quality for 6 months amounting to $R p 22,971,234.44$. The lowest prevention costs are in July and August, namely Rp. 2,090,694.32 with a percentage ratio of $32.26 \%$ and the highest cost of prevention occurred in June, amounting to IDR 1,304,233.96 with a ratio of $38.82 \%$. The lowest assessment fee is in July and August, namely Rp. 1,072,245.97 with a percentage of $15.55 \%$ and the highest appraisal fee occurred in March amounting to Rp. 1,040,000.00, in April amounting to Rp. 1,000,000.00 and in May as much as Rp. 9,20,000.00 with a ratio of $16.67 \%$. And the lowest holding cost is in August of Rp. 952,500.00 with a ratio of $14.70 \%$, and the highest failure cost was in May, amounting to Rp. 1,290,000.00 with a percentage of $23.37 \%$.
\end{abstract}

Key Words: Activity Based Costing, Quality Cost, Pressure Milkfish

\begin{abstract}
Abstrak
UMKM Bandeng Presto Pak Han merupakan usaha rumahan yang bergerak pada pembuatan bandeng presto. Berdasarkan hasil wawancara dengan pemilik usaha, setiap hari dalam produksi pasti ada bandeng presto yang rusak tidak bisa dijual ke pasaran serta dinyatakan produk reject. Rata rata produk reject mencapai pada presentase 4\%-7\% dalam setiap produksi. Produk reject dan sisa penjualan hari itu akan diambil oleh pengepul dan akan dijual kembali setengah harga yang berakibat dengan menurunnya laba yang diterima oleh Bandeng Presto Pak Han. Penelitian bertujuan melakukan perhitungan biaya kualitas yang belum pernah diperhitungkan sebelumnya, serta mengidentifikasi biaya-biaya apa saja yang dikeluarkan dalam upaya meningkatkan kualitas produk serta meningkatkan laba penjualan. Dari pengamataan serta perhitungan dari waktu baku serta perhitungan semua aspek biaya produksi maka disimpulkan metode Activity Based Costing ( $A B C$ Berdasarkan pada hasil pengolahan data yang telah dilakukan dengan Activity Based Costing (ABC) Dari hasil perhitungan biaya kualitas selama 6 bulan sebesar Rp 22.971.234,44. Pada biaya pencegahan paling rendah pada bulan juli dan agustus yaitu Rp. 2.090.694,32 dengan presentase rasio sebesar $32,26 \%$ dan biaya pencegahan paling tinggi terjadi pada bulan
\end{abstract}


juni, sebesar Rp 1.304.233,96 dengan rasio 38,82\%. Pada biaya penilaian paling rendah yaitu pada bulan juli dan agustus yaitu Rp. 1.072.245,97 dengan presentase 15,55\% dan biaya penilaian paling tinggi terjadi pada bulan maret sebesar Rp. 1.040.000,00, pada bulan april sebesar Rp. 1.000.000,00 dan pada bulan mei sebesar Rp. 9.20.000,00 dengan rasio 16,67\%. Serta pada biaya kegagan paling rendah terdapat pada bulan Agustus sebesar Rp. 952.500,00 dengan rasio $14,70 \%$, serta biaya kegagalan paling tinggi terdapat pada bulan mei sebesar Rp. $1.290 .000,00$ dengan presentase $23,37 \%$.

Kata Kunci: Activity Based Costing, Biaya Kualitas, Bandeng Presto

\section{Pendahuluan}

Saat ini perindustrian mulai berkembang pesat dan telah menimbulkan persaingan industri yang dinilai cukup ketat, sehingga mendorong perusahaan atau pelaku usaha untuk dituntut dapat bersaing dengan pesaing usaha lainya. Untuk menghadapi hal ini maka pelaku usaha harus mempunyai strategi yang tepat agar dapat mempertahankan dan meningkatkan posisinya di tengah persaingan yang dihadapi. Salah satu faktor yang mempengaruhi persaingan tersebut adalah faktor kualitas. Kualitas produk dapat mempengaruhi konsumen terhadap penjualan suatu barang untuk memenuhi kepuasan konsumen serta kualitas pada sebuah produk dapat terwujud apabila perusahaan tersebut berorientasi pada konsumen.

UMKM Bandeng Presto Pak Han merupakan usaha rumahan yang bergerak pada pembuatan bandeng presto. Bandeng Presto Pak Han memulai usahanya sejak tahun 2014 dan rumah produksinya berada di daerah Dempel Sari, Tlogosari sekaligus dengan rumah pemilik usaha tersebut. Pada awal berdirinya usaha tersebut, Bandeng Presto Pak Han mempunya 2 macam produk olahan yaitu bandeng presto dan tahu bakso. Setelah berjalan 4 bulan, produksi tahu bakso di berhentikan dengan alasan kurang mampu bersaing pada pasar sekitar, dan akhirnya pemilik usaha hanya memfokusnya usahanya pada bandeng presto saja. Hingga saat ini rata-rata penjualan Bandeng Presto Pak Han mencapai $50 \mathrm{~kg} / \mathrm{hari}$ atau sekitar $150 \mathrm{ekor} / \mathrm{hari}$. Dengan dipasarkan pada 2 buat outlet yang berada di pasar johar dan pasar bulu serta juga melayani pembelian yang ada dirumah Pak Han itu sendiri. Berdasarkan hasil wawancara dengan pemilik usaha, setiap hari dalam setiap produksi pasti ada bandeng presto yang rusak tidak akan dijual ke pasaran serta dinyatakan produk reject. Rata rata produk reject mencapai pada presentase $4 \%-7 \%$ dalam setiap produksi. Produk reject dan sisa penjualan hari itu akan diambil oleh pengepul dan akan dijual kembali setengah harga yang berakibat dengan menurunnya laba yang diterima oleh Bandeng Presto Pak Han.

Berdasarkan hasil wawancara dengan pemilik usaha, hingga saat ini Pihak Bandeng Presto Pak Han sendiri belum pernah melakukan perhitungan biaya kualitas secara mendetail. Hal tersebut akan berimbas pada pengendalian dan perbaikan kualitas. Salah satu cara untuk meningkatkan profit umkm tersebut mengevaluasi pengendalian kualitas serta melakukan perbaikan biaya kualitas. Perhitungan Biaya kulitas pada suatu perusahaan merupalan alat untuk mengidentifikasi sejauh mana funsi pengendalian kualitas yang diterapkan oleh perusahaan.semakin rendahnya hasil perhitiungan biaya kualitas maka menunjukan kerberhasilan program perbaikan kualitas yang dijalankan. Dan tentunya semakin baik produk yang dihasilkan oleh perusahaan, hal tersebut akan mempengaruhi peningkatan penjualan. Meningkatnya penjualan dengan menurunyya biaya produksi tentu akan berimbas pada profitabilitas.

Setelah unsur-unsur biaya diidentifikasi kemudia dapat membuat laporan biaya kualitas. Pelaporan biaya kualitas dinilai penting untun mengetahui seberapa berhasilnya program perbaikan kualitas yang sedang dijalankan oleh UMKM Bandeng Presto Pak Han.

\section{Metode Penelitian Kualitas}

Kualitas merupakan aspek dalam terpenting dalam membrikan pelayanan jasa maupun produk pada setiap setiap perusahaan. jika perusahaan memberikan pelayanan atau produk yang sangat baik, hal tersebut tentu dapat memuaskan konsumen. Kualitas produk adalah kemampuan suatu produk untuk melaksanakan fungsinya meliputi, daya tahan, keandalan, ketepatan, kemudahan operasi, dan perbaikan, serta atribut bernilai lainnya.(Swastha, 2002) 
Biaya

Merupakan salah satu aspek penting dalam berjalanya suatu usaha. Umumnya biaya dihubungkan dengan jenis-jenis organisasi, yaitu organisasi bisnis, organisasi nonbisnis, perusahaan manufaktur, perusahaan dagang, dan perusahaan jasa. Jenis biaya yang terjadi dan cara pengelompokannya, tergantung pada jenis organisasinya. Untuk mengelola suatu perusahaan, diperlukan informasi biaya yang sistematik dan komparatif.(Mustika, Rosalina and Rosita, 2015)

\section{Biaya Kualitas}

mendefinisikan kualitas sebagai ciri dan karakteristik total dari suatu produk atau suatu jasa yang dibuat atau dilakukan menurut spesifikasi untuk memuaskan pelanggan pada saat membeli dan selama penggunaan. Berdasarkan penjelasan diatas dapat disimpulkan bahwa biaya kualitas merupakan standar atau spesifikasi yang dapat memuaskan kebutuhan dan keinginan konsumen. Produk dapat dikatakan berkualitas jika produk tersebut sesuai dengan standar atau spesifikasi yang telah ditetapkan.(Mustika, Rosalina and Rosita, 2015)

\section{Metode ABC}

Metode Activity Based Costing merupakan metode perhitungan biaya yang mempermudah dalam mengelompokkan aspek aspek biaya dalam suatu organisasi. Dari biaya biaya yang seperti biaya biaya overhead, biaya bahan baku, biaya tenaga kerja dialokasikan dalam sebuah jasa atau prduk.(Fauzijah and Zain, 2005).

Dasar dasar sistem biaya ABC ini mencakup biaya produksi tidak langsung, aktivitas, tujuan biaya, pemacu biaya, dan kelompok biaya.

Tabel 1. Performance Rating Berkaitan dengan Sikap Kerja

\begin{tabular}{|c|c|c|}
\hline Faktor & \multicolumn{2}{|c|}{ Kelonggaran } \\
\hline Tenaga Yang Dikeluarkan & Pria & Wanita \\
\hline Dapat Diabaikan & $0-0$ & $0-0,6$ \\
\hline Sangat Ringan & $6-7,5$ & $6-7,5$ \\
\hline Ringan & $7.5-12$ & $7,5-12$ \\
\hline Sdang & $12-19$ & $16-30$ \\
\hline Berat & $19-30$ & \\
\hline Sangat Berat & $30-50$ & \\
\hline \multicolumn{3}{|l|}{ Sikap Kerja } \\
\hline Duduk & \multicolumn{2}{|c|}{$0-1$} \\
\hline Berdiri Diatas Dua Kaki & \multirow{2}{*}{\multicolumn{2}{|c|}{$\frac{1-2,5}{2,5-4}$}} \\
\hline Berdiri Diatas Satu Kaki & & \\
\hline Berbaring & \multicolumn{2}{|c|}{$2,5-4$} \\
\hline Memnungkuk & \multicolumn{2}{|c|}{$4-10$} \\
\hline \multicolumn{3}{|l|}{ Gerakan Normal } \\
\hline Normal & \multicolumn{2}{|c|}{0} \\
\hline Terbatas & \multicolumn{2}{|c|}{$0-5$} \\
\hline Sulit & \multirow{2}{*}{\multicolumn{2}{|c|}{$\frac{0-5}{5-10}$}} \\
\hline Anggota Badan Terbatas & & \\
\hline Sekuruh Anggota Badan Terbatas & \multicolumn{2}{|c|}{$10-15$} \\
\hline Kelelahan Mata & Cahaya Baik & Cahaya Buruk \\
\hline Padangan Terputus Putus & $0-6$ & $0-6$ \\
\hline Pandangan Hampir Terputus & $6-7,5$ & $6-7,5$ \\
\hline Pandangan Terus Menerus Fokus Berubah & 7,5-12 & 7,5-12 \\
\hline Pandangan Terus Menerus Fokus Tetap & $12-19$ & $16-30$ \\
\hline
\end{tabular}

Literatur : (Susilowati, 2019)

Alur perhitungan dengan metode activity based costing $(A B C)$ dari penelitian ini sebagai berikut :

1. Data anggaran pembelian bahan baku dan data reject/rework di UMKM Bandeng Presto Pak Han

2. Perhitungan kebutuhan jumlah tenaga kerja yang sesuai. 
a. Wawancara kepada kepala bagian produksi

b. Meneliti secara langsung pada bagian produksi yaitu dengan mengukur waktu proses produksi dari bahan mentah sampai menjadi produk setengah jadi menggunakan stopwatch.

c. Langkah - langkah yang dilakukan sebelum menentukan waktu baku yaitu:

- Penentuan Performance Rating Operator.

- Waktu Siklus Rata-rata

- Penentuan Waktu Normal.

$$
W s=\frac{\Sigma X_{1}}{N}
$$

\section{Waktu Normal $=$ Ws X Pr (2)}

- Penentuan Allowance (kelonggaran)

$$
\text { WB }=[\text { W siklus } \times \text { RF }] \times \frac{100 \%}{100 \%-A l l \%}
$$

d. Identifikasi aktivitas dan sub aktivitas

Mengidentifikasi aktivitas dan elemen pekerjaan atau sub aktivitas dalam proses produski.

1. Biaya bahan baku

2. Biaya tenaga kerja

biaya tenaga kerja $=$ Jumlah Operator $\times 20$ hari kerja $\times$ Upah perpasang $(R p)(4)$

3. Biaya overhead

e. Perhitungan Biaya aktivitas

1. Biaya bahan baku

2. Biaya tenaga kerja langsung

3. Biaya overhead

4. Biaya kegagalan produk

Biaya sub aktivitas $=$ Pengelompokan biaya aktivitas $\mathrm{x}$ proporsi sub aktivitas (5)

f. Perhitungan Biaya Kualiatas

Biaya Kualitas = Biaya sub aktivitas $\times$ proporsi biaya kualitas (6)

g. Laporan Biaya Kualitas

\section{Pengolahan Data Biaya Kualitas}

Berikut contoh perhitungan biaya sub aktivitas proses produksi pada bulan Maret 2019 pada sub aktivitas 1.

Biaya tenaga kerja

Biaya tenaga kerja bulan maret $=\frac{g a j i}{\text { bulan }} \times J$ umlah Tenaga kerja $\times \frac{\text { hari kerja }}{\text { bulan }}$

$$
=\text { Rp. } 60.000,00 \times 4 \times 26
$$

$=$ Rp. $6 \cdot 240 \cdot 000,00$

$$
\begin{aligned}
\text { Biaya tenaga kerja per sub aktivitas } & =\frac{\text { biaya tenaga kerja }}{\text { jumlah sub aktivitas }} \\
& =\frac{\text { Rp.6.240.000,00 }}{24} \\
& =\operatorname{Rp} .260 .000,00
\end{aligned}
$$

Setelah nilai proporsi sub aktivitas diketahui selanjutnya menghitung biaya sub aktivitas, berikut cara menghitung biaya sub aktivitas :

Biaya sub aktivitas = biaya aktivitas $\mathrm{x}$ proporsi sub aktivitas 
Berikut ini perhitungan untuk biaya sub aktivitas pada bulan maret 2019

Biaya sub aktivitas pembersihan sisik:

= biaya aktivitas $\mathrm{x}$ proporsi sub aktivitas

$=$ Rp. $832.000,00 \times 0,5184$

$=$ Rp. $431.273,00$

Dalam penentuan proporsi setiap sub aktivitas disamaratakan sebesar $100 \%$ atau sama dengan 1. Setelah diketahui proporsi biaya kualitas dan biaya non kualitas, selanjutnya dilakukan perhitungan biaya kualitas untuk setiap elemen biaya kualitas perbulan.

\section{Biaya Kualitas = Biaya sub aktivitas $\mathrm{x}$ Proporsi biaya kualitas}

Berikut ini contoh perhitungan biaya kualitas pada sub sktivitas proses pemeilihan pola pada aktivitas pembersihan sisik dan mensiangi untuk periode bulan maret 2019.

Biaya kualitas bulan maret pada sub aktivitas pembersihan sisik :

Biaya kualitas = proposi sub aktivitas $\times$ biaya tenaga kerja/stasiun $=0,5184 \times$ Rp. $260.000,00$

$=$ Rp. $130.000,00$

Tabel 2. Laporan biaya kualitas Bulan Maret-Mei 2019

\begin{tabular}{|c|c|c|c|c|c|c|}
\hline \multirow{2}{*}{ Deskripsi } & \multicolumn{2}{c|}{ Maret } & \multicolumn{2}{c|}{ April } & \multicolumn{2}{c|}{ Mei } \\
\cline { 2 - 6 } & Jumlah (Rp) & $\%$ & Jumlah (Rp) & $\%$ & Jumlah (Rp) & $\%$ \\
\hline Biaya Aktivitas & $6.240 .000,00$ & & $6.000 .000,00$ & & $5.520 .000,00$ & \\
\hline A. Biaya Pencegahan & & & & & & \\
\hline total biaya pencegahan & $2.132 .000,00$ & 34,17 & $2.028 .712,00$ & 33,81 & $1.866 .416,91$ & 33,81 \\
\hline B. Biaya penlilaian & & & & & & \\
\hline inspeksi bahan-bahan & & & & & & \\
\hline Total biaya penilaian & $1.040 .000,00$ & 16,67 & $1.000 .000,00$ & 16,67 & $920.000,00$ & 16,67 \\
\hline C. Biaya kegagalan (Failure Cost) & & & & & & \\
\hline penjualan bandeng setengah harga & $1.035 .000,00$ & 16,59 & $1.057 .500,00$ & 17,63 & $1.290 .000,00$ & 23,37 \\
\hline Total biaya kegagalan (Failure Cost) & $1.035 .000,00$ & 16,59 & $1.057 .500,00$ & 17,63 & $1.290 .000,00$ & 23,37 \\
\hline \multicolumn{2}{|c|}{} & & & & & \\
\hline total Biaya Kualitas dan Rasio & $4.207 .000,00$ & 67,42 & $4.086 .212,00$ & 68,10 & $4.076 .416,91$ & 73,85 \\
\hline titik Optimal & & 33,71 & & 34,05 & & 36,92 \\
\hline
\end{tabular}

Tabel 3. Laporan biaya kualitas Bulan Juni-Agustus 2019

\begin{tabular}{|c|c|c|c|c|c|c|}
\hline \multirow{2}{*}{ Deskripsi } & \multicolumn{2}{|l|}{ juni } & \multicolumn{2}{|l|}{ juli } & \multicolumn{2}{|c|}{ agustus } \\
\hline & Jumlah (Rp) & $\%$ & Jumlah (Rp) & $\%$ & Jumlah (Rp) & $\%$ \\
\hline A. biaya pencegahan & $6.240 .000,00$ & & $6.000 .000,00$ & & $5.520 .000,00$ & \\
\hline \multicolumn{7}{|l|}{ B. Biaya penlilaian } \\
\hline inspeksi bahan-bahan & $1.981 .580,74$ & 31,76 & $1.884 .487,00$ & 31,41 & $1.733 .721,72$ & 31,41 \\
\hline \multicolumn{7}{|l|}{ Total biaya penilaian } \\
\hline \multicolumn{7}{|l|}{ C. Biaya kegagalan } \\
\hline penjualan bandeng setengah harga & $1.122 .992,00$ & 18,00 & $1.079 .800,00$ & 18,00 & $993.416,00$ & 18,00 \\
\hline \multicolumn{7}{|l|}{ Total biaya kegagalan } \\
\hline & $1.035 .000,00$ & 16,59 & $1.057 .500,00$ & 17,63 & $1.290 .000,00$ & 23,37 \\
\hline total Biaya Kualitas dan Rasio & $1.035 .000,00$ & 16,59 & $1.057 .500,00$ & 17,63 & $1.290 .000,00$ & 23,37 \\
\hline \multicolumn{7}{|l|}{ titik Optimal } \\
\hline & $4.139 .572,74$ & 66,34 & $4.021 .787,00$ & 67,03 & 4.017.137,72 & 72,77 \\
\hline & & 33,17 & & 33,51 & & 36,39 \\
\hline
\end{tabular}




\section{Hasil dan Analisis}

Dari pengumpulan data yang didapatkan dari UMKM Bandeng Presto Pak Han berupa data data yang bersinggungan dengan biaya. Serta pengolahan data yang menghasilkan laporan biaya kulitas. Maka didapatkan analisa sebagai berikut:

\section{i. Prevention Cost}

Hasil perhitungan biaya pencegahan / prevention cost pada bulan maret menunjukkan hasil Rp. 2.132..000,00 dengan rasio 34,17\%. Pada bulan April mengalami penurunan menjadi Rp. 2.028.712,00 dengan rasio sebesar 33,81. Pada bulan Mei biaya pencegahan menunjukan angka Rp.1.866.416,91 dengan rasio 33,81. Pada bulan juni biaya pencegahan mengalami penurunan dengan menunjukan angka Rp. 1.304.233,96 dengan rasio 38,82. Pada bulan juli biaya pencegahan mengalami kenaikan menjadi Rp.2.090.694,32 dengan rasio sebesar 32,26. Pada bulan terakhir yaitu bulan Agustus menunjukan besar biaya pencegahan sebesar Rp. Rp.2.090.694,32 dengan rasio sebesar 32,26.

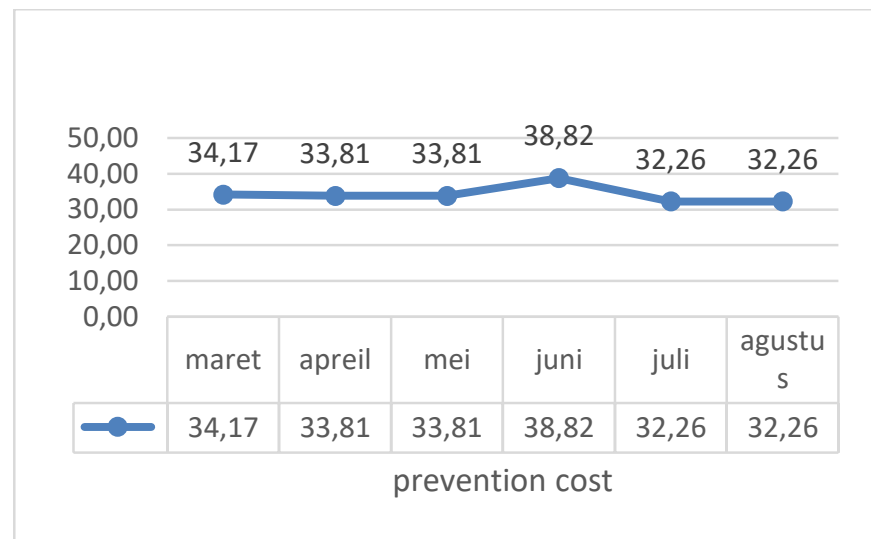

Gambar 1.Grafik Biaya Pencegahan Bulan Maret 2019 - Agustus 2019

\section{ii. Biaya Penilaian}

Pada biaya penilaian bulan maret menunjukan angka Rp.1.040.000,00 dengan rasio 16,67. Pada bulan selanjutnya yaitu bulan April menunjukan biaya penilaian sebesar Rp.1.000.000,00 dengan rasio 16,67. Pada bulan Mei menunjukan angka Rp. 920.000,00 dengan rasio sama dengan bulan april yaitu $16,67 \%$. Pada bulan juni besar biaya penilaian mencapai Rp. 504.000,00 dengan rasio sebesar 15\%. Pada bulan juli dan agustus biaya penilaian mengalami kenaikan yang sama hingga $\mathrm{Rp}$ 1.072.245,97 dengan rasio 16.55 .

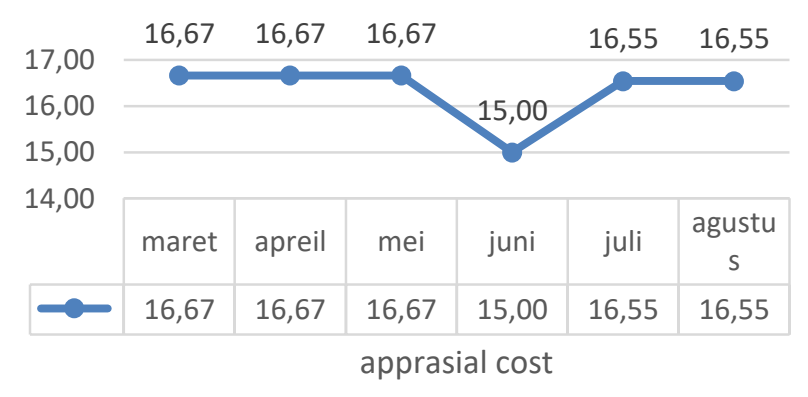

Gambar 2. Grafik Biaya Penliaian Bulan Maret 2019 - Agustus 2019

\section{iii. Biaya Kegagalan}

Biaya kegagalan pada Bandeng Presto Pak Han sendiri tidak masuk dalam perhitungan proporsi. Pasalnya besar biaya kegagalan didapat dari penjualan produk reject dan penjualan sisa bandeng pada 2 outlet. Pada bulan maret biaya kegagalan mencapai Rp. $1.035 .000,00$ dengan rasio $16,59 \%$. Sedangkan pad bulan april mengalami kenaikan menjadi 
Rp 1.057.500,00 dengan menunjukan rasio sebesar $17,63 \%$. Pada bulan mei besar biaya kegagalan mencapai $\mathrm{Rp} 1.290 .000,00$ dengan rasio sebesar 23,37\%. Pada bulan juni mengalami penurunan produksi hingga besaran biaya kegagaglanya sebesar $R p$ 547.500,00 dengan rasio sebesar 16,29. Pada bulan juni biaya kegagalan mencapai Rp 967.500,00 dengan besar rasio 14,93. Dan pada bulan terakhir perhitungan biaya kualitas yaitu bulan Agustus sebesar Rp 952.500,00 dengan rasio sebesar 14,7\%

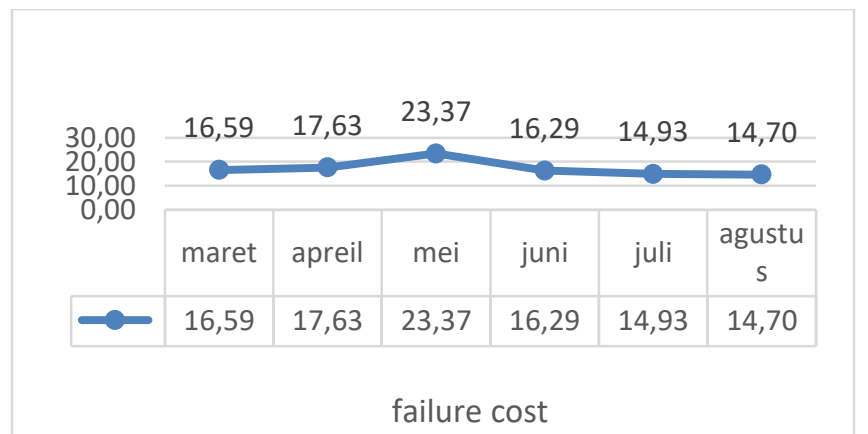

Gambar 3. Grafik Biaya Kegagalan Bulan Maret 2019 - Agustus 2019

Dari grafik tersebut terdapat data yang fluktuatif dari bulan ke bulan. Namun grafik tersebut tidak menjadi patokan biaya kualitas yang naik ataupun menurun. Karena pada setiap bulannya jumlah produksi Bandeng Presto Pak Han tidak sama.

\section{Kesimpulan}

Berdasarkan hasil penelitian mengenai perhitungan biaya kualitas yang telah dilakukan pada UMKM Bandeng Presto Pak Han dapat diambil kesimpulan sebagai berikut:

1. Aspek aspek biaya produksi yang digunakan untuk produksi antara lain

- Biaya bahan baku dan bahan baku penolong contoh ikan bandeng, garam bumbu, pewarna dll.

- Biaya overhead, contoh biaya listrik, biaya air, bahan bakan kendaraan, gas LPG dill.

- Biaya tenaga kerja

2. Dalam proses produksi UMKM Bandeng Presto Pak Han masih terdapat reject yang mengakibatkan bandeng hanya dapat dijual setengah harga terhadap pengepul.

3. Berdasarkan pada hasil pengolahan data yang telah dilakukan dengan Activity Based Costing (ABC) Dari hasil perhitungan biaya kualitas selama 6 bulan sebesar Rp 22.971.234,44. Pada biaya pencegahan paling rendah pada bulan juli dan agustus yaitu Rp. 2.090.694,32 dengan presentase rasio sebesar $32,26 \%$ dan biaya pencegahan paling tinggi terjadi pada bulan juni, sebesar Rp 1.304.233,96 dengan rasio $38,82 \%$. Pada biaya penilaian paling rendah yaitu pada bulan juli dan agustus yaitu Rp. 1.072.245,97 dengan presentase 15,55\% dan biaya penilaian paling tinggi terjadi pada bulan maret sebesar Rp. 1.040.000,00, pada bulan april sebesar Rp. $1.000 .000,00$ dan pada bulan mei sebesar Rp. 9.20.000,00 dengan rasio 16,67\%. Serta pada biaya kegagan paling rendah terdapat pada bulan Agustus sebesar Rp. $952.500,00$ dengan rasio $14,70 \%$, serta biaya kegagalan paling tinggi terdapat pada bulan mei sebesar Rp. 1.290.000,00 dengan presentase $23,37 \%$.

4. Berdasarkan analisa diatas, penjualan bandeng setengah harga masih banyak. Hal tersebut dapat mengurangi laba, apabila penjualan bandeng yang dijual setengah harga dapat dijual sesuai dengan harga standar maka hal itu akan lebih memberikan laba besar terhadap profit UMKM Bandeng Presto Pak Han, yaitu dengan cara melakukan penekanan defect produksi dan mengubah strategi penjualan untuk mengurangi sisa bandeng yang tidak laku terjual pada hari itu. 


\section{Referensi}

[1] I. D. Agustami Silviana, "ANALISA PERBANDINGAN SISTEM TRADISIONAL DENGAN SISTEM ACTIVITY BASED COSTING DALAM PERHITUNGAN HARGA POKOK PRODUSI DI PT. PINDAD (PERSERO)," J. Ris. AKUNTASI DAN Keuang. , vol. 2(1), no., pp. 261-268, 2014, doi: 10.1017/CBO9781107415324.004.

[2] Z. H. Alfi Syahr, A. Purwanti, and I. G. K. Agung Ulupui, "Analisis Komparasi Biaya Pendidikan Antara Metode Tradisional Dengan Activity Based Costing System Pada Madrasah Diniyah Al-Burhaniyah," J. Organ. dan Manaj., vol. 12, no. 1, pp. 39-53, 2016, doi: 10.33830/jom.v12i1.32.2016.

[3] H. Batubara, "Harga Pokok," vol. 1, no. 3, pp. 217-224, 2013.

[4] Y. N. A. E. Retno Maninggarjati, Yulius Gessong Sampeallo, "ANALISIS PERHITUNGAN HARGA POKOK KAMAR HOTEL DENGAN MENGGUNAKAN METODE ACTIVITY BASED COSTING (ABC) (Studi Kasus: Swiss Belhotel Borneo Samarinda)," vol. 15, no. 2, pp. 24-33, 2019.

[5] A. Fachroji, "Penentuan Harga Pokok Produksi Menggunakan Metode ABC di PT TMG. Surabaya," J. Ind. Eng. Manag., vol. 3, no. 2, pp. 172-185, 2012.

[6] A. Fauzijah and M. Y. Zain, "Aplikasi Penentuan Harga Jual Kamar pada Perusahaan Jasa Perhotelan Menggunakan Metode Activity Based Costing (ABC)," Media Inform., vol. 3, no. 1 , pp. 1-10, 2005, doi: 10.20885/informatika.vol3.iss1.art1.

[7] S. Hafizah, Dea Fadilla; Arifulsyah, Hamdani; Nurulita, "Penerapan Akuntansi Diferensial dalam Pengambilan Keputusan Menjual atau Memproduksi Lebih Lanjut Produk Cacat," J. Akunt. Keuang. dan bisnis, vol. 10, no. 1, pp. 21-28, 2017.

[8] L. Hidayat and S. Halim, "Analisis Biaya Produksi Dalam Meningkatkan Profitabilitas Perusahaan," J. IIm. Manaj. Kesatuan, vol. 1, no. 2, pp. 159-168, 2013, doi: 10.37641/jimkes.v1i2.263.

[9] R. Kaban, "Pengendalian Kualitas Kemasan Plastik Pouch Menggunakan Statistical Procces Control (SPC) di PT Incasi Raya Padang," J. Optimasi Sist. Ind., vol. 13, no. 1, p. 518, 2016, doi: 10.25077/josi.v13.n1.p518-547.2014.

[10] C. Y. A. Mawitjere and H. Karamoy, "Jurnal Riset Akuntansi Going Concern FE Unsrat Jurnal Riset Akuntansi Going Concern FE Unsrat," pp. 21-41, 2000.

[11] S. Mdp, "Simulasi Pelaporan Biaya Kualitas Di PT . XYZ Terkait Dengan Penerapan ISO 9000 : 2000," vol. 1, no. 1, pp. 55-64, 2011.

[12] R. Mustika, E. Rosalina, and I. Rosita, "Penerapan Biaya Kualitas Dalam Meningkatkan Efisiensi Biaya Produksi Pada Catering ABC," J. Akunt. Manaj., vol. 10, no. 1, pp. 25-35, 2015.

[13] R. A. Nanik Lestari, Patricia Diana P, "Penerapan Metode Activity Based Costing Dalam Penentuan Harga Pokok Produksi Pakan," pp. 1-16, 2017.

[14] D. I. Rinawati, D. P. Sari, and F. Muljadi, "Penentuan Waktu Standar Dan Jumlah Tenaga Kerja Optimal Pada Produksi Batik Cap (Studi Kasus: Ikm Batik Saud Effendy, Laweyan)," J@Ti Undip J. Tek. Ind., vol. 7, no. 3, pp. 143-150, 2013, doi: 10.12777/jati.7.3.143-150.

[15] V. Rizalt and P. Bambang, "Perhitungan Cost of Quality Dengan Menggunakan Metode Activity Based Costing Untuk Menjaga Kualitas Antar Proses Produksi. Studi kasus (PT BERKAT JAYA MANUNGGAL)," vol. 1, pp. 1-10, 2018.

[16] SUHARTINI, "Perencanaan Kebutuhan Material Dengan Metode Material Requirement Planning," J. Tek. Ind., vol. 15, no. 2, p. 190, 2016, doi: 10.22219/jtiumm.vol15.no2.190200.

[17] Susilowati, "LAPORAN TUGAS AKHIR PERHITUNGAN COST OF QUALITY DENGAN MENGGUNAKAAN METODE ACTIVITY BASED COSTING (ABC) UNTUK MENGETAHUI BIAYA KEGAGALAN PRODUKSI PADA CV ISO RUBBER," Uiversitas Islam Sultan Agung, 2019.

[18] B. Swastha, "Pengaruh Kualitas Produk Dan Harga Terhadap Keputusan Pembelian Produk Kosmetik Wardah Di Kota Bangkalan Madura," J. Ekon. , Bisnis Entrep., vol. 1, no. 1, pp. 31-48, 2002.

[19] K. Wahyuningtias, "Pengaruh Biaya Kualitas Terhadap Produk Rusak Pada Cv. Ake Abadi," J. Ris. Ekon. Manajemen, Bisnis dan Akunt., vol. 1, no. 3, pp. 321-330, 2013.

[20] I. G. A. Widyadana, "PENINGKATAN EFEKTIFITAS DAN EFISIENSI BIAYA KUALITAS MELALUI PENEDEKATAN SIMULASI (Studi Kasus di CV. SINAR BAJA ELEKTRIC)," J. Tek. Ind., vol. 5, no. 1, pp. 63-70, 2003, doi: 10.9744/jti.5.1.pp.63-70. 
[21] A. Winardi, "Analisis Perlakuan Produk Rusak Dan Produk Cacat Dalam Perhitungan Biaya Produksi Untuk Menentukan Harga Jual Produk Pada UD. Susana Baru," Ekon. Akunt., vol. 01, no. 08, pp. 1-13, 2016. 